\title{
Geostatistical evaluation of lead and zinc concentration in soils of an old mining area with complex land management
}

\author{
J. Zawadzki • P. Fabijańczyk
}

Received: 6 March 2012/Revised: 11 May 2012/Accepted: 9 October 2012/Published online: 30 October 2012

(C) The Author(s) 2012. This article is published with open access at Springerlink.com

\begin{abstract}
This study is aimed at detailed statistical and geostatistical investigation of lead and zinc concentration in an old mining area located in the eastern part of the Upper Silesian Industrial Region. This area is rich in lead and zinc ores whose intense extraction dates back to the tenth century AD. The complexity of the area results from historical and current mining activities, as well as from a variety of different types of land management and complex geological conditions. Almost 1,000 collected soil cores were divided into two subsets: those collected at the depth of up to $20 \mathrm{~cm}$ and the those collected at the depth from 40 to $60 \mathrm{~cm}$. Extensive analyses considered geological substrata in terms of spatial variability and spatial distributions, the type of land management, geoaccumulation indexes and enrichment factors. Lead and zinc concentration was several times higher on depths ranging from 40 to $60 \mathrm{~cm}$ beneath the soil surface than in the $20-\mathrm{cm}$ topsoil. The results showed that clearer spatial dependence was observed for deeper soil layers then for the topmost ones, especially near mines where anthropogenic factors predominated over lithogenic ones. Weak spatial dependence was accompanied by high values of the geoaccumulation index. The lowest concentrations of pollution with geoaccumulation index below 0 and enrichment factor up to 5 observed in the forest were caused by low anthropogenic pressure and the presence of sandy soils, less capable of accumulating heavy metals.
\end{abstract}

\footnotetext{
J. Zawadzki · P. Fabijańczyk ( $₫)$ Environmental Engineering Faculty, Warsaw University of Technology, Nowowiejska 20, 00-653 Warsaw, Poland e-mail: p.fabijanczyk@gmail.com

J. Zawadzki

e-mail: j.j.zawadzki@gmail.com
}

Keywords Soil pollution in mining area - Lead and zinc pollution · Geostatistics · Geoaccumulation index . Enrichment factor

\section{Introduction}

Soil pollution with heavy metals has become a cause for concern in many countries. Previous studies showed that the concentration of heavy metals in soils may vary depending on the intensity of numerous factors of anthropogenic and natural origin (Sutherland 2000; Gallego et al. 2002; Saby et al. 2006; Magiera and Zawadzki 2007; Zawadzki and Fabijańczyk 2008; Morton-Bermea et al. 2009; Wei and Yang 2009; Maas et al. 2010; Hani and Pazira 2011). Mining is considered to be one of the most dangerous anthropogenic activities affecting soil quality. Another important factor is the presence of industrial sources of pollution, like smelters, coal burning plants or cement mills (Hulett et al. 1980). Here, the distance from sources of pollution is essential (Albasel and Cottenie 1985). Studies also showed that there is a clear connection between the distance and the load of heavy metals that get into the soil. Moreover, the type of land management can be an important factor. For example, significant differences were found in concentrations of heavy metals in soils in forested, open and arable areas (Magiera et al. 2006; Magiera and Zawadzki 2007). These differences depended on the type of soil, plowing and cultivating. Furthermore, the distribution of heavy metals and their concentration on particular soil horizons varied according to the type of land management, soil composition and chemical processes influencing the mobility of heavy metals within the soil profile (Ettler et al. 2005). Concurrent occurrence of all of the above mentioned factors makes the studies of soil 
pollution in mining areas extremely complex (Qishlaqi et al. 1997; Strzyszcz and Magiera 1998; Cabala et al. 2004; Cabala 2009). For this reason using geostatistical methods in the description of spatial distribution of soil pollution in such areas seems essential.

Soil contamination with heavy metals can persist long after finishing the mining activity and pose environmental risks to the population living in a contaminated area. Although distribution of heavy metals in soils has already been studied for many mining sites, there are still very few well-documented studies of soil contamination, especially in the areas where zinc $(\mathrm{Zn})$ and lead $(\mathrm{Pb})$ ore mining has been carried out for many centuries.

The study area was located within the Upper Silesian Industrial Area (USIA), which is one of the most contaminated areas in Poland. USIA was previously intensively studied for heavy-metal soil pollution (Strzyszcz and Magiera 1998; Lis and Pasieczna 1999; Cabala et al. 2004; Cabala 2009). Numerous chemical and geophysical investigations were performed, and they all confirmed high concentrations of heavy metals in soil. However, thorough spatial analyses combining classic statistics and spatial techniques are still needed.

The study area is characterized by the intense mining and ore exploration of $\mathrm{Pb}$ and $\mathrm{Zn}$ ores, and consequently soil pollution with $\mathrm{Pb}$ and $\mathrm{Zn}$ is strongly related to this type of industry. Accordingly, $\mathrm{Pb}$ and $\mathrm{Zn}$ were chosen to be analyzed because they were common components of ore deposits located within the study area.

In order to analyze the concentration of $\mathrm{Pb}$ and $\mathrm{Zn}$ in soil, a large and very detailed measuring campaign was carried out. Almost a thousand soil cores were collected in the studied area. They were divided into two subsets: those collected at the depth of up to $20 \mathrm{~cm}$ and the ones collected at the depth from 40 to $60 \mathrm{~cm}$. Due to the high complexity of USIA in terms of the type of land management, mining activity, and geological substrata, all analyses took all these factors into thorough consideration. Obtained results can be in particular relevant to the mining areas characterized by intense $\mathrm{Pb}$ and $\mathrm{Zn}$ ore exploration. Especially, the results of this study may be valuable for those interested in soil pollution with heavy metals in USIA.

\section{Study area}

The study area covered almost $150 \mathrm{~km}^{2}$ and was located in the vicinity of an old mining town Sławków in the Silesian district, in southern Poland. It is estimated that the mining of silver and lead existed there as early as the 10th century, but the most intense mining took place in the 18th and 19th century. Sławków surroundings are characterized by rather complex land management. The town is located at the western edge of the study area and was the largest residential territory in this region. The central part of the study area is mostly occupied by arable lands with a moderately dense net of paved roads and sparse residential buildings, whereas the northern and southern parts are mostly covered with forests composed of coniferous trees.

The study area was also characterized by significant anthropogenic influence caused by numerous industrial factories. A galvanization factory, located at the eastern edge of the study area is a serious source of heavy-metal pollution caused by chemical substances used during galvanization processes and a large waste dump resultant to floating processes. Other sources of anthropogenic pressure are associated with mines like "Bolesław" and "OlkuszPomorzany" located near the galvanization factory. The large expanse in the southern part of the study area was mostly used in the past for ore extraction.

The types of land management were determined using the Corine Land Cover database (Bossard et al. 2000) and then were verified using orthophoto maps. As a result, the following types of land management were delineated (Fig. 1):

i. Farmlands-individually cultivated regions, located in the center of the study area.

ii. Forests-dense forest stands located mostly in the northern and the south-western part of the study area. Sparsely wooded areas were not included herein.

iii. Post-mining area-areas used in the past for mining, at present covered by shrubs, unpaved roads and closed old landfills.

iv. Roadside areas - terrains located up to $50 \mathrm{~m}$ away from public, paved roads.

v. Industrial areas-ore mines, steelworks and a galvanization factory, etc.

In the study area the geological substrata were determined using geological maps made at the Polish Geological Institute (Lis and Pasieczna 1999). These substrata were grouped into three classes (Fig. 1):

i. Loams, dolomites, limestones, marlstones.

ii. Sands and gravels, eolian sands.

iii. Loess.

The whole study area was covered with ores rich in sulfides of $\mathrm{Pb}$ and $\mathrm{Zn}$ (Cabala et al. 2004; Cabala 2009), sulfides of $\mathrm{Fe}$ and also carbonates of $\mathrm{Pb}$ and $\mathrm{Zn}$. Especially, theses ores occurred in places where the dolomites, limestones and marlstones were deposited. At some locations, mostly in the eastern and southern part of the study area, $\mathrm{Pb}$ and $\mathrm{Zn}$ ores were covered only with a thin layer of eolian sands. Intense ore exploration caused natural soils to be highly degraded or even almost completely removed in some locations. For this reason, initial or industrial soils were predominant at the study area. 


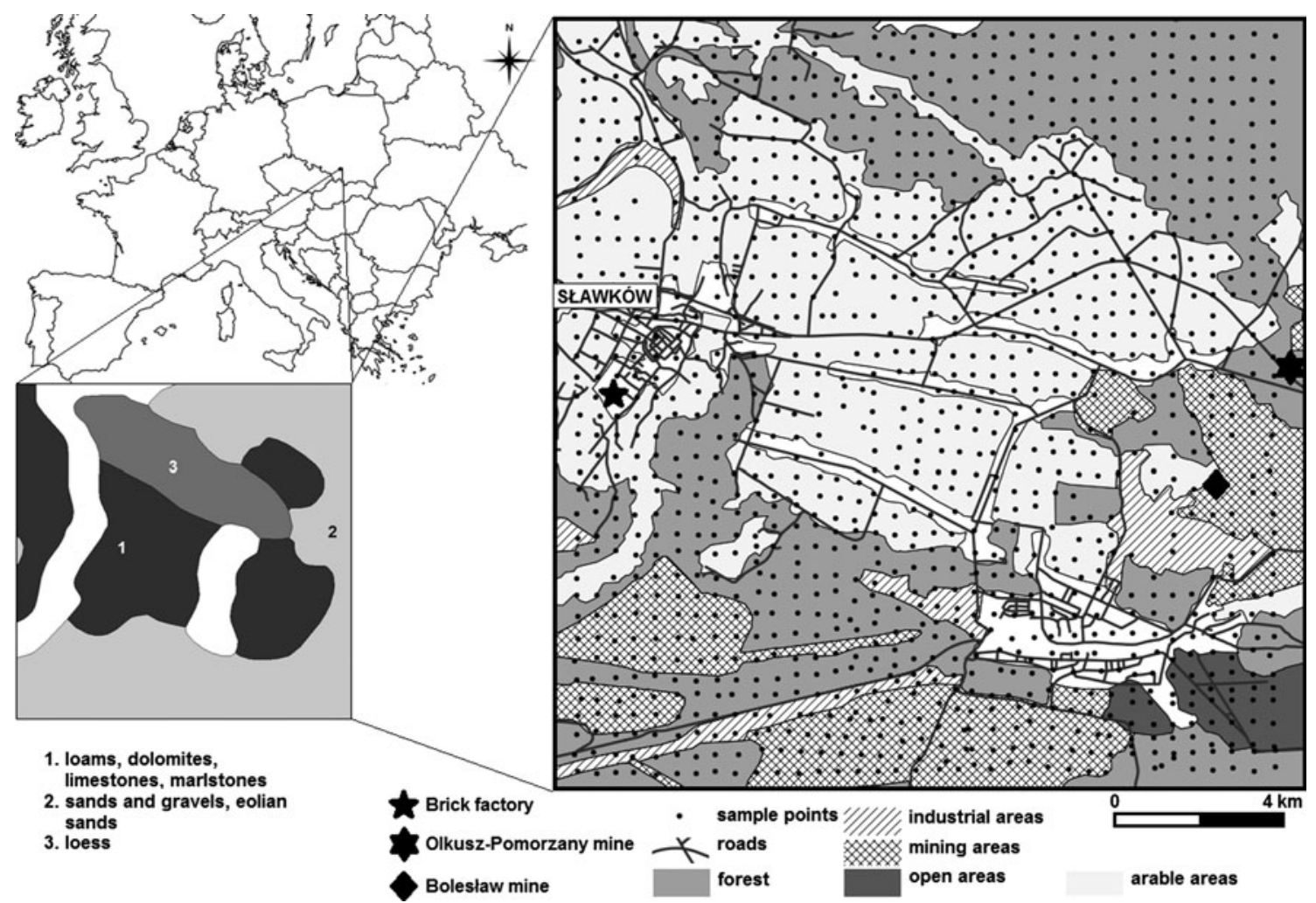

Fig. 1 Study area, locations of sample points and geological composition of area

The study area was divided into 11 groups, considering both the type of land management and geological substrata (Table 1).

\section{Materials and methods}

Samples collection and chemical analyses

Sample points were evenly distributed over the study area and an average distance between sample points equaled $250 \mathrm{~m}$. Over a 1,000 soil cores were collected using a soil probe with a diameter of $8 \mathrm{~cm}$. Subsequently, 60-cm-long

Table 1 Determined groups considering the type of land management and geological substratum

\begin{tabular}{lllc}
\hline & $\begin{array}{l}\text { Loams, dolomites, } \\
\text { limestones, } \\
\text { marlstones }\end{array}$ & $\begin{array}{l}\text { Sands and } \\
\text { gravels, eolian } \\
\text { sands }\end{array}$ & Loess \\
\hline Forest & + & + & + \\
Post-mining area & - & + & - \\
Arable areas & + & - & + \\
Areas near roads & + & + & + \\
Industrial areas & + & + & - \\
\hline
\end{tabular}

The "-" sign denotes that such a group was not present at the study area cores were divided into two kinds of subsamples. The subsamples of the first kind, denoted below as level 1, were parts of the soil cores down to the depth of $20 \mathrm{~cm}$ beneath the soil surface, whereas the subsamples of the second kind, referred to as level 2, were parts of the soil cores down to the depth of from 40 to $60 \mathrm{~cm}$.

In the laboratory, subsamples of both types (i.e., level 1 and level 2) were digested using $\mathrm{HCl}$ and heated at the temperature of $90{ }^{\circ} \mathrm{C}$ for $1 \mathrm{~h}$. Afterward, $100 \mathrm{ml}$ of each subsample was used for the determination of $\mathrm{Pb}$ and $\mathrm{Zn}$ by inductively coupled plasma mass spectrometry (ICP-MS), using the spectrometer Philips PV 8060. The collection of soil samples and laboratory analyses was performed by the Polish Geological Institute (Lis and Pasieczna 1999).

\section{Statistical and geostatistical analyses}

All analyses were carried out separately for each of the 11 groups of the soil type, the land management and geological substrata. Statistical analyses were carried out using Statistica 10. They included calculation of basic descriptive statistics, box-and-whisker plots, the Pearson correlation coefficients, as well as selected statistical tests.

Spatial variability of $\mathrm{Pb}$ and $\mathrm{Zn}$ concentration in soil was analyzed using variograms. Their parameters, like the range of correlation and the nugget-to-sill ratio were 
carefully determined to get deeper insight into the spatial dependence of the studied phenomena. The nugget-to-sill ratio belonged to the following three ranges: less than 0.25 , between 0.25 and 0.75 , or higher than 0.75 that corresponded to strong, moderate or weak spatial dependence, respectively (Cambardella et al. 1994).

Spatial maps of $\mathrm{Pb}$ and $\mathrm{Zn}$ concentration in soil were calculated using ordinary kriging (Isaaks and Srivastava 1989; Bierkens 1997; Goovaerts 1997). All calculations, including data preparation, analyses of orthophoto maps and Corine Land Cover database, were made using free software QGIS and SAGA with selected plugins.

Geoaccumulation index and enrichment factor

Apart from the spatial distributions of $\mathrm{Pb}$ and $\mathrm{Zn}$ concentration in soil, a geoaccumulation index (IG) was calculated. This indicator was previously used to assess the soil pollution (Rubio et al. 2000), and was defined as:

$\mathrm{IG}=\log _{2} \frac{C_{n}}{1.5 \times B_{n}}$,

where: $C_{n}$ is measured concentration of $\mathrm{Pb}$ or $\mathrm{Zn}, B_{n}$ is the geochemical background of $\mathrm{Pb}$ or $\mathrm{Zn}$.

In addition, the enrichment factor (EF) was calculated that was frequently previously used to assess the extent of soil pollution with heavy metals. In order to calculate EF, it was also necessary to measure the Fe concentration in soil (Loska et al. 1997; Reimann and De Caritat 2000).

$\mathrm{EF}=\frac{\left(\frac{M_{\text {sample }}}{\mathrm{Fe}_{\text {sample }}}\right)}{\left(\frac{M_{\text {background }}}{\mathrm{Fe}_{\text {background }}}\right)}$

where: $M_{\text {sample }}, M_{\text {background }}$ is measured and background concentration of $\mathrm{Pb}$ or $\mathrm{Zn}, \mathrm{Fe}_{\text {sample }}, \mathrm{Fe}_{\text {background }}$ is measured and background concentration of $\mathrm{Fe}$.

The values of IG and EF were calculated for each sample point and afterward they were used to calculate spatial distributions using ordinary kriging method. Then the obtained values of IG and EF were divided into classes according to soil pollution (Loska et al. 1997; Maas et al. 2010) (Table 2). Background concentrations used in the
Eqs. 1 and 2 were determined based on the average concentrations in soils located in the same part of Poland as the study area, and characterized with low anthropogenic pressure.

\section{Results and discussion}

Concentration of $\mathrm{Pb}$ and $\mathrm{Zn}$ on levels 1 and 2

Descriptive statistics of $\mathrm{Pb}$ and $\mathrm{Zn}$ concentration in soil on both levels 1 and 2 (Tables 3 and 4) were calculated after the outlying values, those lower or higher than the average by two standard deviations were removed from the dataset. Almost all extreme values were observed near dumps of the Bolesław mine. The removal of such extreme values was beneficial in further analyses of spatial variability and spatial interpolation with kriging method.

Maximum concentrations of $\mathrm{Pb}$ in soil on both levels 1 and 2 for the majority of types of the land management were up to several times higher than admissible values according to the standards that are in effect in Poland, i.e., equal to $600 \mathrm{mg} / \mathrm{kg}$ for industrial areas, and $100 \mathrm{mg} / \mathrm{kg}$ for the rest of areas analyzed in this study (Fig. 2).

Post-mining areas located on sands were characterized by the lowest concentrations of $\mathrm{Pb}$ on both levels. This part of the study site was used for mining in the past, but at present the anthropogenic pressure is rather low.

In forest area $\mathrm{Pb}$ concentrations were rather low on both levels. Significantly higher values were observed in the industrial areas, and in the roadside areas, $50 \mathrm{~m}$ away from major, paved roads. Such observation, especially for level 1 , may suggest that the main source of $\mathrm{Pb}$ pollution was connected with industrial activity and traffic.

For arable areas located on loamy soils, the Zn concentrations on the level 1 were significantly higher than on the level 2, but in the case of arable areas located at loess these differences were negligible. This may result from the depositions of industrial dusts originated from the "Bolesław" mine, located $3 \mathrm{~km}$ to the east, and its dumps. The predominant wind directions in the study area are usually south-west, west, and east. The majority of
Table 2 Threshold values of geoaccumulation index and enrichment factor

\begin{tabular}{llll}
\hline IG & Contamination & EF & Contamination \\
\hline$>5$ & Very strong & $<2$ & Depletion to minimal enrichment \\
$4-5$ & Strong to very strong & $2-5$ & Moderate enrichment \\
$3-4$ & Strong & $5-20$ & Significant enrichment \\
$2-3$ & Moderate to strong & $20-40$ & Very high enrichment \\
$1-2$ & Moderate & $>40$ & Extremely high enrichment \\
$0-1$ & Uncontaminated to moderate & & \\
$<0$ & Practically uncontaminated & & \\
\hline
\end{tabular}


Table 3 Descriptive statistics of Pb concentration in soil on levels 1 and 2, grouped by the type of land management and geological substratum

\begin{tabular}{|c|c|c|c|c|c|c|c|c|}
\hline & Level & Mean & Median & Min & Max & $\mathrm{Q}_{25 \%}$ & $\mathrm{Q}_{75 \%}$ & SD \\
\hline \multirow[t]{2}{*}{ Arable-loamy } & 1 & 71.7 & 52.0 & 2.5 & 338.0 & 30.0 & 95.0 & 62.4 \\
\hline & 2 & 157.3 & 151.0 & 22.0 & 350.0 & 96.0 & 205.0 & 70.1 \\
\hline \multirow[t]{2}{*}{ Arable-loess } & 1 & 15.9 & 13.0 & 6.0 & 70.0 & 10.0 & 16.5 & 11.4 \\
\hline & 2 & 118.5 & 99.5 & 15.0 & 431.0 & 80.0 & 157.0 & 74.9 \\
\hline \multirow[t]{2}{*}{ Post-mining area-sandy } & 1 & 4.2 & 2.5 & 2.5 & 17.0 & 2.5 & 6.0 & 2.9 \\
\hline & 2 & 14.0 & 6.0 & 2.5 & 87.0 & 2.5 & 13.0 & 20.0 \\
\hline \multirow[t]{2}{*}{ Forest-loamy } & 1 & 18.5 & 13.0 & 2.5 & 73.0 & 8.0 & 28.0 & 15.3 \\
\hline & 2 & 106.6 & 90.0 & 7.0 & 310.0 & 62.0 & 124.0 & 68.6 \\
\hline \multirow[t]{2}{*}{ Forest-loess } & 1 & 12.1 & 11.0 & 2.5 & 30.0 & 9.0 & 15.0 & 5.5 \\
\hline & 2 & 99.6 & 97.0 & 25.0 & 202.0 & 83.0 & 120.0 & 37.4 \\
\hline \multirow[t]{2}{*}{ Forest-sands } & 1 & 14.3 & 7.0 & 2.5 & 155.0 & 2.50 & 12.0 & 24.2 \\
\hline & 2 & 60.0 & 49.0 & 2.5 & 281.0 & 28.0 & 73.0 & 50.8 \\
\hline \multirow[t]{2}{*}{ Industrial-loamy } & 1 & 171.3 & 126.5 & 8.0 & 471.0 & 61.5 & 239.0 & 137.9 \\
\hline & 2 & 911.1 & 930.5 & 49.0 & $1,967.0$ & 648.0 & $1,093.0$ & 503.1 \\
\hline \multirow[t]{2}{*}{ Industrial-sandy } & 1 & 106.9 & 48.0 & 7.0 & 528.0 & 30.0 & 92.0 & 143.5 \\
\hline & 2 & 363.4 & 206.0 & 23.0 & $1,669.0$ & 131.0 & 430.0 & 381.8 \\
\hline \multirow[t]{2}{*}{ Roads-loamy } & 1 & 132.5 & 90.0 & 2.5 & 524.0 & 29.5 & 204.5 & 128.3 \\
\hline & 2 & 216.3 & 168.5 & 18.0 & 609.0 & 94.0 & 320.0 & 150.4 \\
\hline \multirow[t]{2}{*}{ Roads-loess } & 1 & 25.1 & 14.5 & 2.50 & 143.0 & 8.5 & 18.0 & 35.6 \\
\hline & 2 & 101.8 & 79.5 & 23.0 & 223.0 & 54.5 & 142.0 & 63.1 \\
\hline \multirow[t]{2}{*}{ Roads-sands } & 1 & 47.8 & 8.0 & 2.50 & 360.0 & 2.50 & 45.0 & 82.7 \\
\hline & 2 & 118.9 & 61.0 & 2.50 & 830.0 & 21.00 & 141.0 & 167.1 \\
\hline
\end{tabular}

The values are given in $(\mathrm{mg} / \mathrm{kg})$

industrial dusts are transported away by winds from the arable areas, except for the eastern winds that could transport them directly to the arable fields (Fig. 3).

In forest areas, $\mathrm{Zn}$ concentrations were the highest for loamy soils, medium for loess and the lowest for sands and gravels. Forests placed on loams and loess were located about $3 \mathrm{~km}$ west from "Olkusz-Pomorzany" to "Boleslaw" mines, so they were directly exposed to the industrial dusts transported by predominant winds, and later accumulated in organic and humic horizons. Accordingly, $\mathrm{Zn}$ concentrations were significantly higher on the level 1 than on the level 2.

Forests situated on sands and gravel were located mainly in the southern part of the study site, so they were less exposed to the anthropogenic pressure. As a result the $\mathrm{Zn}$ concentrations were up to several times lower than in forests situated on loams and loess. However, in the forests situated on sands, high concentrations of $\mathrm{Zn}$ were also observed on the level 2, but it was connected with the natural lithogenic presence of ores.

The highest concentrations of $\mathrm{Zn}$ on level 1 in areas located at a distance of $50 \mathrm{~m}$ from roads were observed for sands and gravels, lower for loess and the lowest for loams. Such values were observed because roads located on sands and partially on loess were situated near mines where anthropogenic pressure was very high, connected also with the road transport of extracted ores. Roads situated on loams were located mostly around Sławków, where the predominant pollution was associated rather with $\mathrm{Pb}$, coming from traffic, than with $\mathrm{Zn}$. It was clearly visible in the case of $\mathrm{Pb}$ concentrations, especially on the level 1, that were higher for roads located on loams than for roads located on sands and loess. High $\mathrm{Zn}$ concentrations, reaching up to $7,000 \mathrm{mg} / \mathrm{kg}$, on the level 2 at loamy soils located $50 \mathrm{~m}$ away from roads were strictly connected with the presence of ores (Fig. 4).

The concentration of $\mathrm{Pb}$ and $\mathrm{Zn}$ on the level 2 was significantly higher than on the level 1, practically for the entire study area. The highest differences were observed in the areas used for industrial purposes, medium on farmlands and the lowest in post-mining areas and forest that is strongly correlated with the presence of ores rich in $\mathrm{Pb}$ and $\mathrm{Zn}$. The highest differences of $\mathrm{Pb}$ concentration between levels 1 and 2 reached almost $1,000 \mathrm{mg} / \mathrm{kg}$, while the lowest were below $20 \mathrm{mg} / \mathrm{kg}$. The differences in $\mathrm{Zn}$ concentrations were even higher, reaching almost $3,000 \mathrm{mg} / \mathrm{kg}$ in the vicinity of the mine Bolesław where major geological substrata were loams, limestones, marlstones and dolomites, closely associated with the presence of lead and zinc deposits. The lowest differences in 
Table 4 Descriptive statistics of $\mathrm{Zn}$ concentration in soil on levels 1 and 2, grouped by the type of land management and geological substratum

\begin{tabular}{|c|c|c|c|c|c|c|c|c|}
\hline & Level & Mean & Median & Min & Max & $\mathrm{Q}_{25 \%}$ & $\mathrm{Q}_{75 \%}$ & SD \\
\hline \multirow[t]{2}{*}{ Arable-loamy } & 1 & 470.2 & 294.0 & 17.0 & $2,595.0$ & 122.0 & 504.0 & 556.5 \\
\hline & 2 & 57.2 & 48.0 & 26.0 & 320.0 & 35.0 & 60.5 & 45.7 \\
\hline \multirow[t]{2}{*}{ Arable-loess } & 1 & 38.9 & 29.5 & 12.0 & 109.0 & 22.0 & 47.0 & 23.5 \\
\hline & 2 & 44.3 & 45.0 & 8.0 & 84.0 & 35.5 & 52.0 & 15.5 \\
\hline \multirow[t]{2}{*}{ Post-mining area-sandy } & 1 & 32.5 & 22.0 & 5.0 & 568.0 & 14.0 & 35.0 & 45.2 \\
\hline & 2 & 16.2 & 13.0 & 5.0 & 39.0 & 11.0 & 21.0 & 7.4 \\
\hline \multirow[t]{2}{*}{ Forest-loamy } & 1 & $1,002.0$ & 765.5 & 25.0 & $3,298.0$ & 290.5 & $1,474.5$ & 917.8 \\
\hline & 2 & 343.9 & 131.0 & 39.0 & $1,415.0$ & 86.0 & 530.0 & 388.6 \\
\hline \multirow[t]{2}{*}{ Forest-loess } & 1 & 551.4 & 270.0 & 18.0 & $2,487.0$ & 88.5 & 721.0 & 677.9 \\
\hline & 2 & 45.8 & 45.0 & 16.0 & 72.0 & 37.0 & 60.0 & 15.7 \\
\hline \multirow[t]{2}{*}{ Forest-sands } & 1 & 124.3 & 36.0 & 9.0 & 736.0 & 19.0 & 85.0 & 195.7 \\
\hline & 2 & 692.4 & 547.0 & 78.0 & $2,347.0$ & 361.0 & 880.0 & 480.1 \\
\hline \multirow[t]{2}{*}{ Industrial-loamy } & 1 & 305.4 & 273.0 & 48.0 & 721.0 & 188.0 & 362.0 & 177.1 \\
\hline & 2 & 212.4 & 186.5 & 34.0 & 520.0 & 134.0 & 269.5 & 116.3 \\
\hline \multirow[t]{2}{*}{ Industrial-sandy } & 1 & 149.1 & 147.0 & 34.0 & 352.0 & 100.0 & 194.5 & 69.9 \\
\hline & 2 & 115.8 & 86.0 & 4.0 & 729.0 & 46.0 & 156.0 & 104.7 \\
\hline \multirow[t]{2}{*}{ Roads-loamy } & 1 & 39.3 & 22.0 & 7.0 & 194.0 & 17.0 & 46.0 & 40.1 \\
\hline & 2 & $3,108.1$ & $2,784.0$ & 175.0 & $7,392.0$ & $1,867.0$ & $4,146.0$ & $1,797.0$ \\
\hline \multirow[t]{2}{*}{ Roads-loess } & 1 & $1,413.9$ & 897.0 & 155.0 & $6,856.0$ & 425.0 & $1,485.0$ & $1,735.6$ \\
\hline & 2 & 898.9 & 530.0 & 85.0 & $2,720.0$ & 284.0 & $1,453.0$ & 812.1 \\
\hline \multirow[t]{2}{*}{ Roads-sands } & 1 & 302.3 & 234.0 & 56.0 & 657.0 & 126.0 & 472.0 & 190.6 \\
\hline & 2 & 312.9 & 145.0 & 13.0 & $1,694.0$ & 59.0 & 402.0 & 409.5 \\
\hline
\end{tabular}

The values are given in $(\mathrm{mg} / \mathrm{kg})$

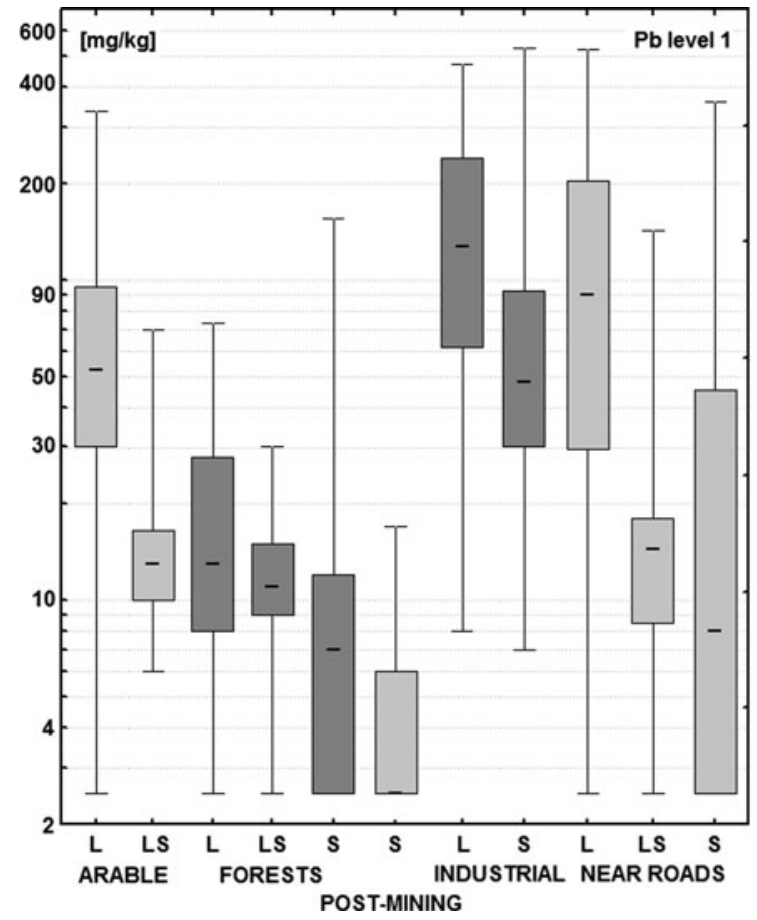

Fig. 2 Box-and-whisker plots (minimum, $25 \%$ quartile, median, $75 \%$ quartile, maximum) of $\mathrm{Pb}$ concentration in soil on the level 1 and 2, grouped by the type of land management and geological

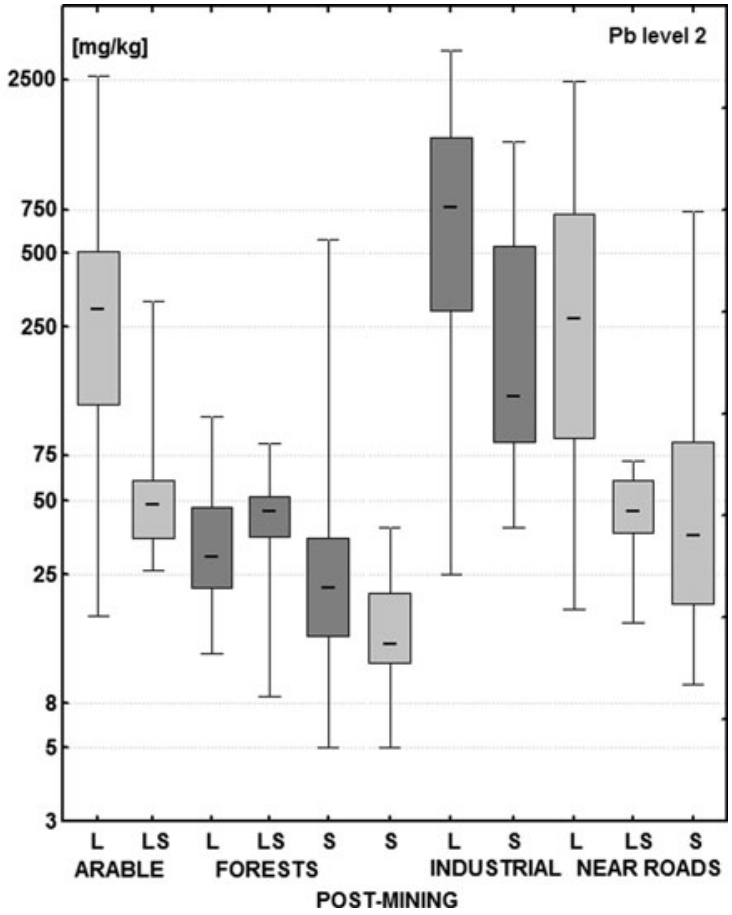

substratum; L-loams, dolomites, limestones, marlstones; S-sands and gravels, eolian sands; LS-loess; vertical axis is on logarithmic scale 


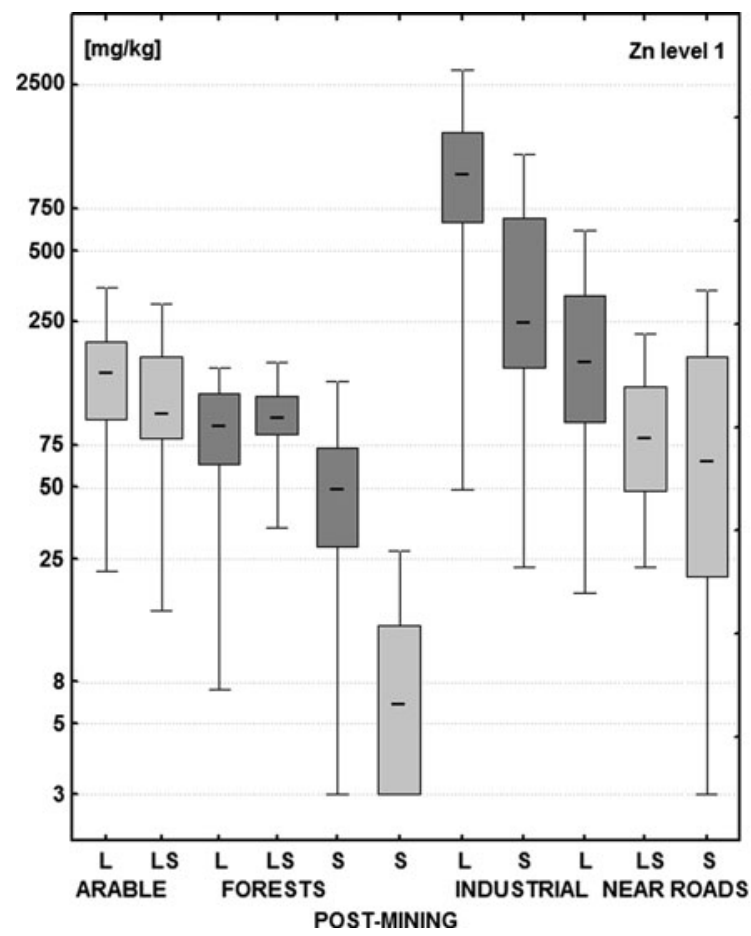

Fig. 3 Box-and-whisker plots (minimum, $25 \%$ quartile, median, $75 \%$ quartile, maximum) of $\mathrm{Zn}$ concentration in soil on the level 1 and 2 , grouped by the type of land management and geological

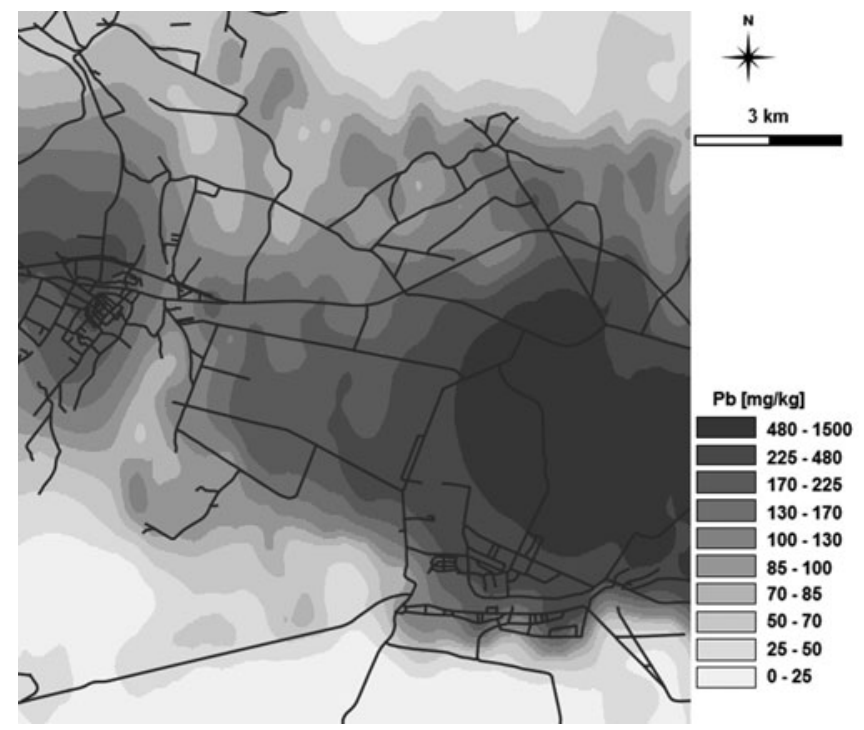

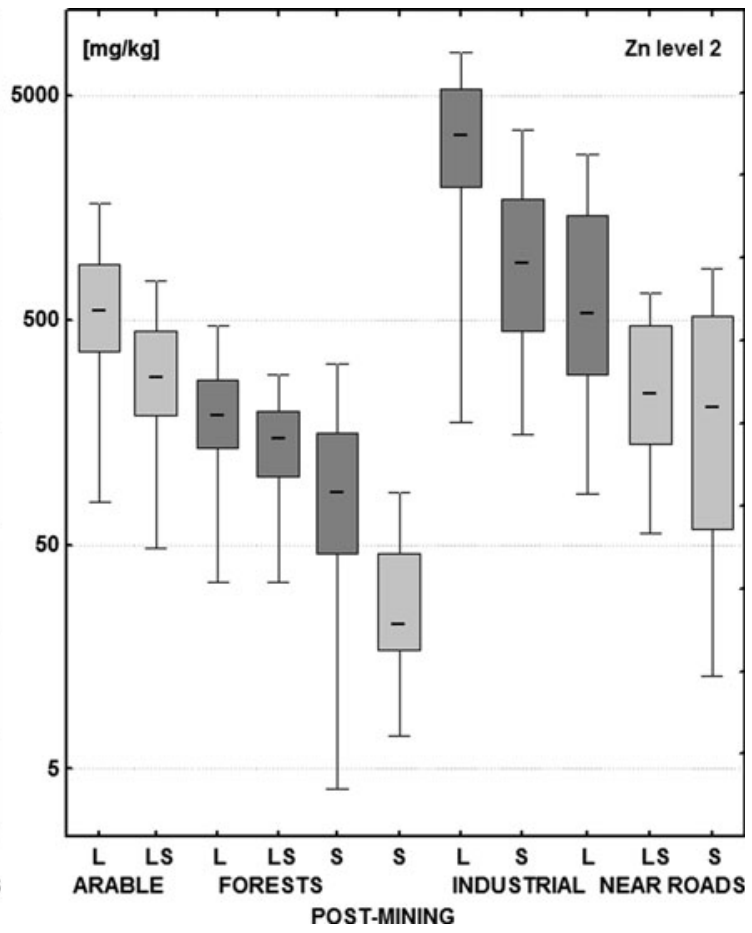

substratum; L-loams, dolomites, limestones, marlstones; S—sands and gravels, eolian sands; LS-loess; vertical axis is on logarithmic scale

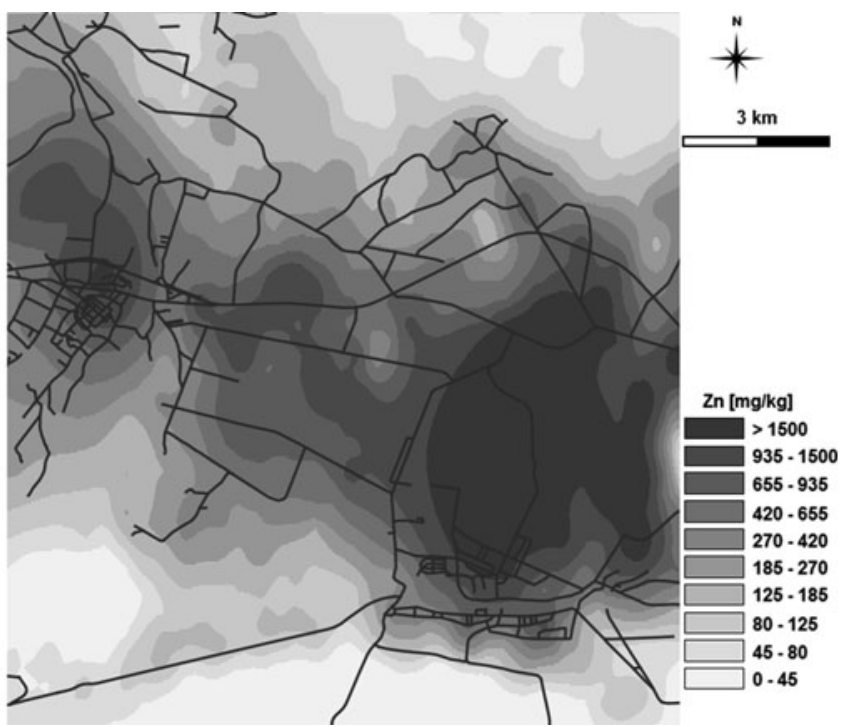

Fig. 4 Differences in $\mathrm{Pb}$ and $\mathrm{Zn}$ concentration in soil between levels 2 and 1

concentration of $\mathrm{Zn}$ between levels 1 and 2 were observed in post-mining areas and forests (below $100 \mathrm{mg} / \mathrm{kg}$ ), where the sands, gravels and eolian sands were predominant.

Higher concentration of $\mathrm{Pb}$ and $\mathrm{Zn}$ on the level 2 was related mostly to the structure of the soil profile and the occurrence of the ore-bearing dolomites. Usually, in soils with significant anthropogenic pollution but with irrelevant lithogenic influence the highest concentration of $\mathrm{Pb}$ and $\mathrm{Zn}$ were observed on a depth of about 5 to $10 \mathrm{~cm}$. In soils where lithogenic factor was more substantial, the increase of heavy metals concentration was observed along with the increase of the depth in soil profile (Magiera et al. 2006). Soils in the study area were subjected to the strong 
anthropogenic pollution but also significant lithogenic influence was observed.

Furthermore, we analyzed the correlations between concentrations of $\mathrm{Zn}$ and $\mathrm{Pb}$ on the same level (level 1 or level 2) as well as the correlations between concentrations of $\mathrm{Zn}$ and $\mathrm{Pb}$ on the different levels (between level 1 and the level 2). Concentration of $\mathrm{Zn}$ and $\mathrm{Pb}$ on the level 1 showed a strong relationship for areas with strong anthropogenic pressure, mostly in the vicinity of mines (Table 5). Weaker correlations were observed in arable areas on the level 1, which may be the result of cultivation processes that blend the upper layer of the soil, and reduce correlations between these heavy metals. The forest areas located on loams, loess and sands, were characterized by weak correlations between the concentration of $\mathrm{Pb}$ and $\mathrm{Zn}$, for both level 1 and 2. Correlations between concentration of $\mathrm{Pb}$ and $\mathrm{Zn}$ on different levels were negligible in most cases.

Spatial correlations of $\mathrm{Pb}$ and $\mathrm{Zn}$ concentrations

Spatial correlations were investigated for all areas, except from areas near roads, which were omitted because of the specific layout of the sample points, located along the paved roads and consequently irregularly scattered through the entire study area. Accordingly, calculated variograms might not be precise or reliable. For the remaining groups experimental variograms were calculated and modeled, using a spherical model, for which parameters were compared to find out how they relate to the type of land management and geological substratum (Tables 6 and 7).
Table 5 Pearson correlation coefficients between $\mathrm{Pb}$ and $\mathrm{Zn}$ concentrations on levels 1 and 2 , grouped by the type of land management and geological substratum

Coefficient marked with italics area insignificant at $\alpha=0.05$

\begin{tabular}{lllcc}
\hline & $\mathrm{Pb} \mathrm{1-Zn} \mathrm{1}$ & $\mathrm{Pb} 2-\mathrm{Zn} \mathrm{2}$ & $\mathrm{Pb} \mathrm{1-Zn} \mathrm{2}$ & $\mathrm{Pb} 2-\mathrm{Zn} \mathrm{1}$ \\
\hline Arable-loamy & 0.81 & 0.76 & 0.62 & 0.34 \\
Arable-loess & 0.85 & 0.80 & 0.44 & 0.45 \\
Forest-loamy & 0.42 & 0.53 & -0.04 & 0.20 \\
Forest-loess & 0.42 & 0.22 & 0.04 & 0.11 \\
Forest-sandy & 0.64 & 0.66 & 0.19 & 0.22 \\
Industrial areas-loamy & 0.92 & 0.71 & 0.34 & 0.04 \\
Industrial areas-sandy & 0.91 & 0.92 & 0.23 & 0.20 \\
Areas near roads-loamy & 0.85 & 0.83 & 0.40 & 0.37 \\
Areas near roads-loess & 0.67 & 0.90 & 0.24 & 0.21 \\
Areas near roads-sandy & 0.91 & 0.98 & 0.89 & 0.77 \\
Post-mining area-sandy & 0.66 & 0.86 & 0.25 & 0.34 \\
\hline
\end{tabular}

Table 6 Parameters of variograms of $\mathrm{Pb}$ concentration on levels 1 and 2, grouped by the type of land management and geological substratum

\begin{tabular}{|c|c|c|c|c|c|c|c|c|}
\hline \multirow[t]{2}{*}{ Area, soil type } & \multirow[t]{2}{*}{ Level } & \multirow[t]{2}{*}{ Nugget $\left(\mathrm{mg}^{2} / \mathrm{kg}^{2}\right)$} & \multirow[t]{2}{*}{ Sill $\left(\mathrm{mg}^{2} / \mathrm{kg}^{2}\right)$} & \multirow[t]{2}{*}{ Range $(\mathrm{km})$} & \multirow[t]{2}{*}{ Nugget-to-sill ratio (-) } & \multicolumn{3}{|c|}{ Level 1 to level 2 ratio } \\
\hline & & & & & & Nugget $(\%)$ & Sill $(\%)$ & Range $(\%)$ \\
\hline \multirow[t]{2}{*}{ Industrial-L } & 1 & - & - & - & - & - & - & - \\
\hline & 2 & $10^{5}$ & $54 \times 10^{4}$ & 0.75 & 0.19 & & & \\
\hline \multirow[t]{2}{*}{ Industrial-S } & 1 & - & - & - & - & - & - & - \\
\hline & 2 & $11 \times 10^{4}$ & $37 \times 10^{4}$ & 0.67 & 0.23 & & & \\
\hline \multirow[t]{2}{*}{ Post-mining-S } & 1 & 5.5 & 9.5 & 1.70 & 0.58 & 5 & 2 & 117 \\
\hline & 2 & 110 & 420 & 1.45 & 0.26 & & & \\
\hline \multirow[t]{2}{*}{ Arable-L } & 1 & 2,000 & 4,500 & 1.25 & 0.44 & 333 & 101 & 86 \\
\hline & 2 & 600 & 4,450 & 1.45 & 0.13 & & & \\
\hline \multirow[t]{2}{*}{ Arable-LS } & 1 & 380 & 535 & 0.71 & 0.64 & 760 & 9 & 89 \\
\hline & 2 & 50 & 5,450 & 0.80 & 0.01 & & & \\
\hline \multirow[t]{2}{*}{ Forest-S } & 1 & 250 & 720 & 2.80 & 0.35 & 28 & 21 & 88 \\
\hline & 2 & 900 & 3,400 & 3.20 & 0.26 & & & \\
\hline \multirow[t]{2}{*}{ Forest-LS } & 1 & 8 & 33 & 0.95 & 0.24 & - & - & - \\
\hline & 2 & - & - & - & - & & & \\
\hline
\end{tabular}

L-loams, dolomites, limestones, marlstones; S—sands and gravels, eolian sands; LS-loess 
Table 7 Parameters of variograms of Zn concentration on levels 1 and 2, grouped by the type of land management and geological substratum

\begin{tabular}{|c|c|c|c|c|c|c|c|c|}
\hline \multirow[t]{2}{*}{ Area, soil type } & \multirow[t]{2}{*}{ Level } & \multirow[t]{2}{*}{ Nugget $\left(\mathrm{mg}^{2} / \mathrm{kg}^{2}\right)$} & \multirow[t]{2}{*}{ Sill $\left(\mathrm{mg}^{2} / \mathrm{kg}^{2}\right)$} & \multirow[t]{2}{*}{ Range (km) } & \multirow[t]{2}{*}{ Nugget-to-sill ratio (\%) } & \multicolumn{3}{|c|}{ Level 1 to level 2 ratio } \\
\hline & & & & & & Nugget $(\%)$ & Sill $(\%)$ & Range (\%) \\
\hline \multirow[t]{2}{*}{ Industrial-L } & 1 & $5 \times 10^{6}$ & $19 \times 10^{6}$ & 0.95 & 26 & \multirow[t]{2}{*}{333} & \multirow[t]{2}{*}{432} & \multirow[t]{2}{*}{95} \\
\hline & 2 & $15 \times 10^{5}$ & $44 \times 10^{5}$ & 1.00 & 34 & & & \\
\hline \multirow[t]{2}{*}{ Industrial-S } & 1 & $10^{5}$ & $11 \times 10^{5}$ & 0.55 & 10 & \multirow[t]{2}{*}{13} & \multirow[t]{2}{*}{33} & \multirow[t]{2}{*}{63} \\
\hline & 2 & $8 \times 10^{5}$ & $33 \times 10^{5}$ & 0.87 & 24 & & & \\
\hline \multirow[t]{2}{*}{ Post-mining-S } & 1 & 37 & 61 & 2.00 & 61 & \multirow[t]{2}{*}{12} & \multirow[t]{2}{*}{3} & \multirow[t]{2}{*}{108} \\
\hline & 2 & 300 & 1,950 & 1.85 & 15 & & & \\
\hline \multirow[t]{2}{*}{ Arable-L } & 1 & $12 \times 10^{4}$ & $46 \times 10^{4}$ & 1.60 & 29 & \multirow[t]{2}{*}{8} & \multirow[t]{2}{*}{170} & \multirow[t]{2}{*}{145} \\
\hline & 2 & $15 \times 10^{3}$ & $27 \times 10^{4}$ & 1.10 & 24 & & & \\
\hline \multirow[t]{2}{*}{ Arable-LS } & 1 & 2,750 & 7,150 & 0.95 & 38 & \multirow[t]{2}{*}{69} & \multirow[t]{2}{*}{17} & \multirow[t]{2}{*}{63} \\
\hline & 2 & 4,000 & 43,000 & 1.50 & 10 & & & \\
\hline \multirow[t]{2}{*}{ Forest-S } & 1 & 700 & 2,800 & 2.40 & 25 & \multirow[t]{2}{*}{23} & \multirow[t]{2}{*}{22} & \multirow[t]{2}{*}{75} \\
\hline & 2 & 3,000 & 12,500 & 3.20 & 24 & & & \\
\hline \multirow[t]{2}{*}{ Forest-LS } & 1 & 20 & 232 & 0.46 & 9 & \multirow[t]{2}{*}{1} & \multirow[t]{2}{*}{5} & \multirow[t]{2}{*}{66} \\
\hline & 2 & 2,700 & 5,000 & 0.70 & 54 & & & \\
\hline
\end{tabular}

L-loams, dolomites, limestones, marlstones; S-sands and gravels, eolian sands; LS-loess
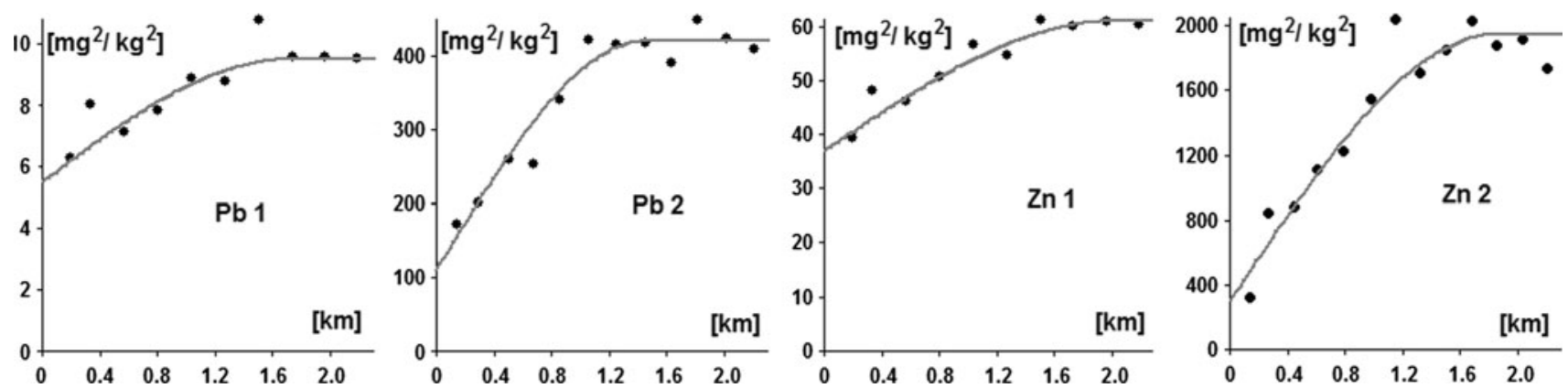

Fig. 5 Semivariograms and its models for $\mathrm{Pb}$ and $\mathrm{Zn}$ concentration in soils on post-mining area located on sands

For the majority of areas, correlation range for the level 1 was up to $76 \%$ shorter than the correlation range for the level 2. It can be explained by the fact that the topmost soil was more subjected to anthropogenic factors such as industrial dusts, and also mostly composed of organic and humic horizons which were more spatially variable, due to the soil processes. The level 2, located beneath it, was mostly composed of subsoil and parent rock where abovedescribed processes are negligible. In the case of postmining area, for both $\mathrm{Pb}$ and $\mathrm{Zn}$, the correlation range for the level 1 was up to $17 \%$ longer than that for the level 2, what can be the result of the past mining activity. At this region the topmost soil was highly processed in the past due to open-cast mining. At present, this area is covered with forest and shrubs, and consequently, the amount of anthropogenic pressure is low. Moreover, due to the dominant wind blow directions industrial dust from local mines are transported rather away from this area.
Industrial areas were characterized by a short range of correlation for $\mathrm{Zn}$ concentration on both soil levels, and $\mathrm{Pb}$ concentration revealed no visible spatial correlations and its variogram was modeled using only pure nugget. Relatively weak spatial correlation may be the result of strong industrial activity that strongly transformed the topmost soil layers. In addition, a significant number of extreme values and the highest values of semivariance were observed, especially in case of $\mathrm{Pb}$ concentration (Fig. 5).

For arable areas located on loamy soils, significantly high values of semivariance were observed, especially in the case of $\mathrm{Zn}$ concentration that was caused by the presence of ore-rich dolomites and the vicinity of mines "Bolesław" and "Olkusz-Pomorzany". Despite the high semivariance values, the correlation ranges were easily visible on variograms, and longer than those for industrial areas, slightly shorter than those for post-mining areas and almost two times shorter than those for forests. In the case 

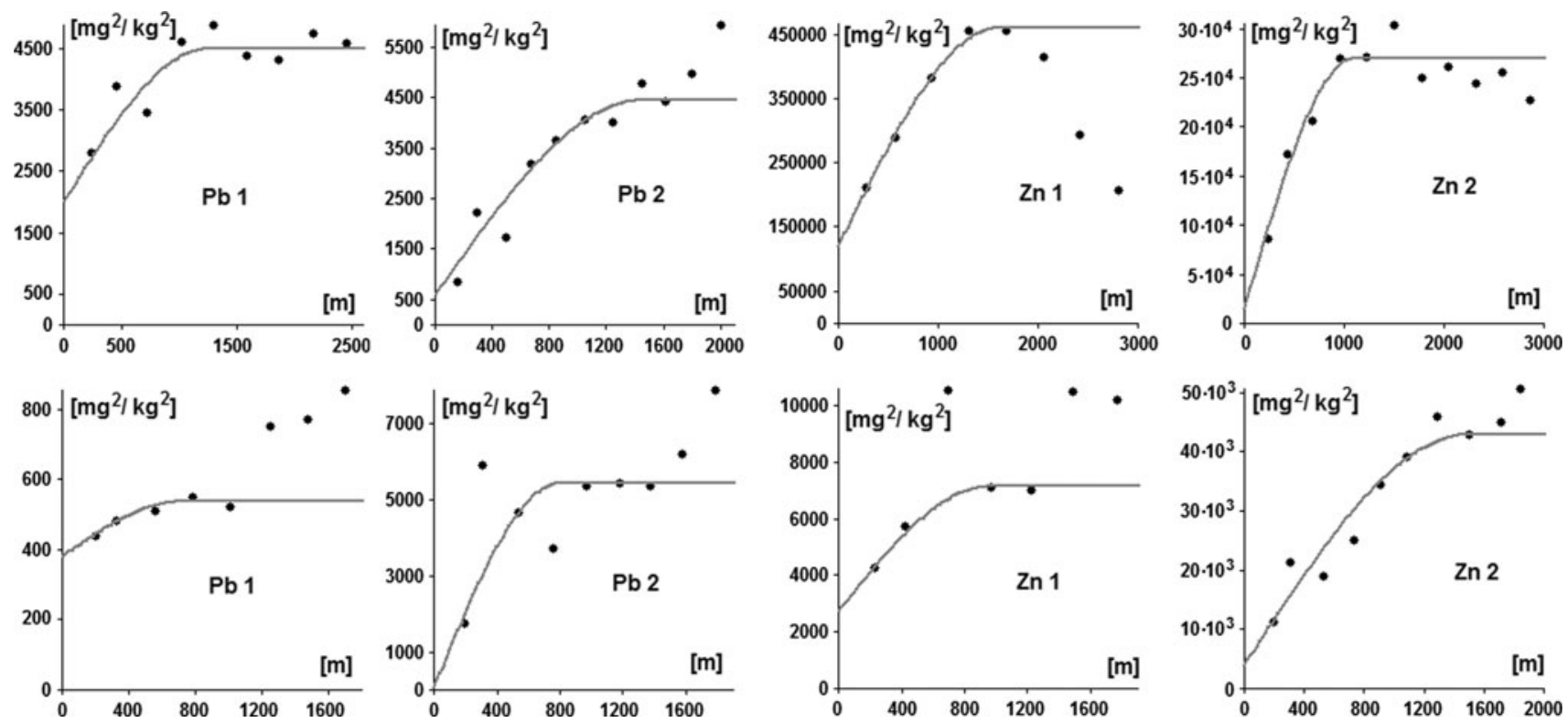

Fig. 6 Semivariograms and its models for $\mathrm{Pb}$ and $\mathrm{Zn}$ concentration in soils on arable areas located on loamy soils (upper row) and on loess (lower row)
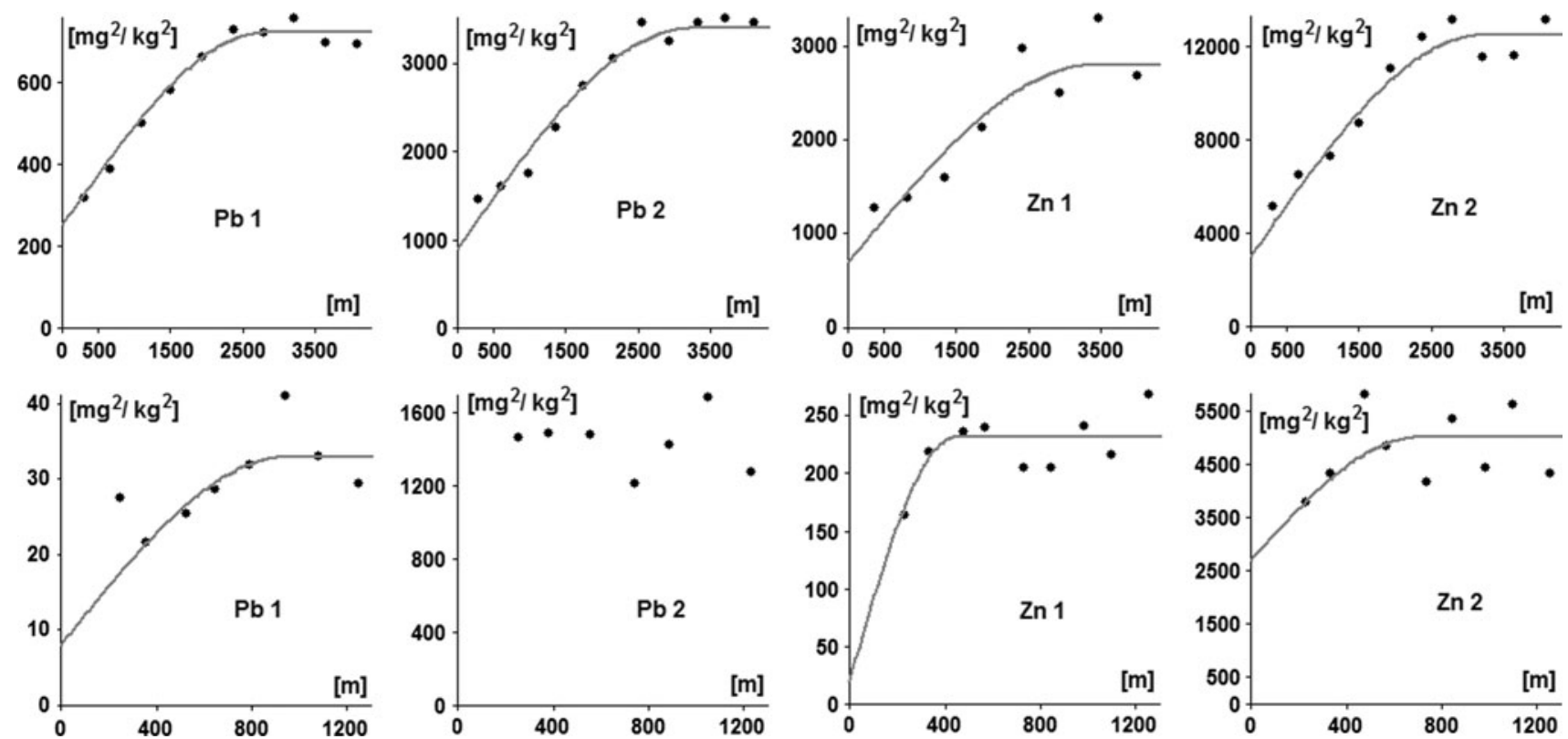

Fig. 7 Semivariograms and its models for $\mathrm{Pb}$ and $\mathrm{Zn}$ concentration in soil in forests located on sands (upper row) and on loess (lower row)

of $\mathrm{Zn}$ concentration in soil, the range of correlations for the level 1 was about $45 \%$ longer than that for the level 2. Such observation may be due to agricultural processes that cause the upper soil layer to be mixed, and consequently, more homogenous (Fig. 6).

Concentrations of $\mathrm{Pb}$ and $\mathrm{Zn}$ in forest areas located on loess were characterized by rather poor spatial correlations, especially for the level 2, for which $\mathrm{Pb}$ concentration revealed almost no spatial correlations. However, it may be caused by a small number of samples which additionally are irregularly distributed on the study site.

Concentrations of both $\mathrm{Pb}$ and $\mathrm{Zn}$ in soil in forest areas located on sands revealed the most relevant spatial correlations. Experimental variograms were easy to be modeled, and fitted models were characterized by the longest correlation ranges (over $3 \mathrm{~km}$ ) (Fig. 7). 


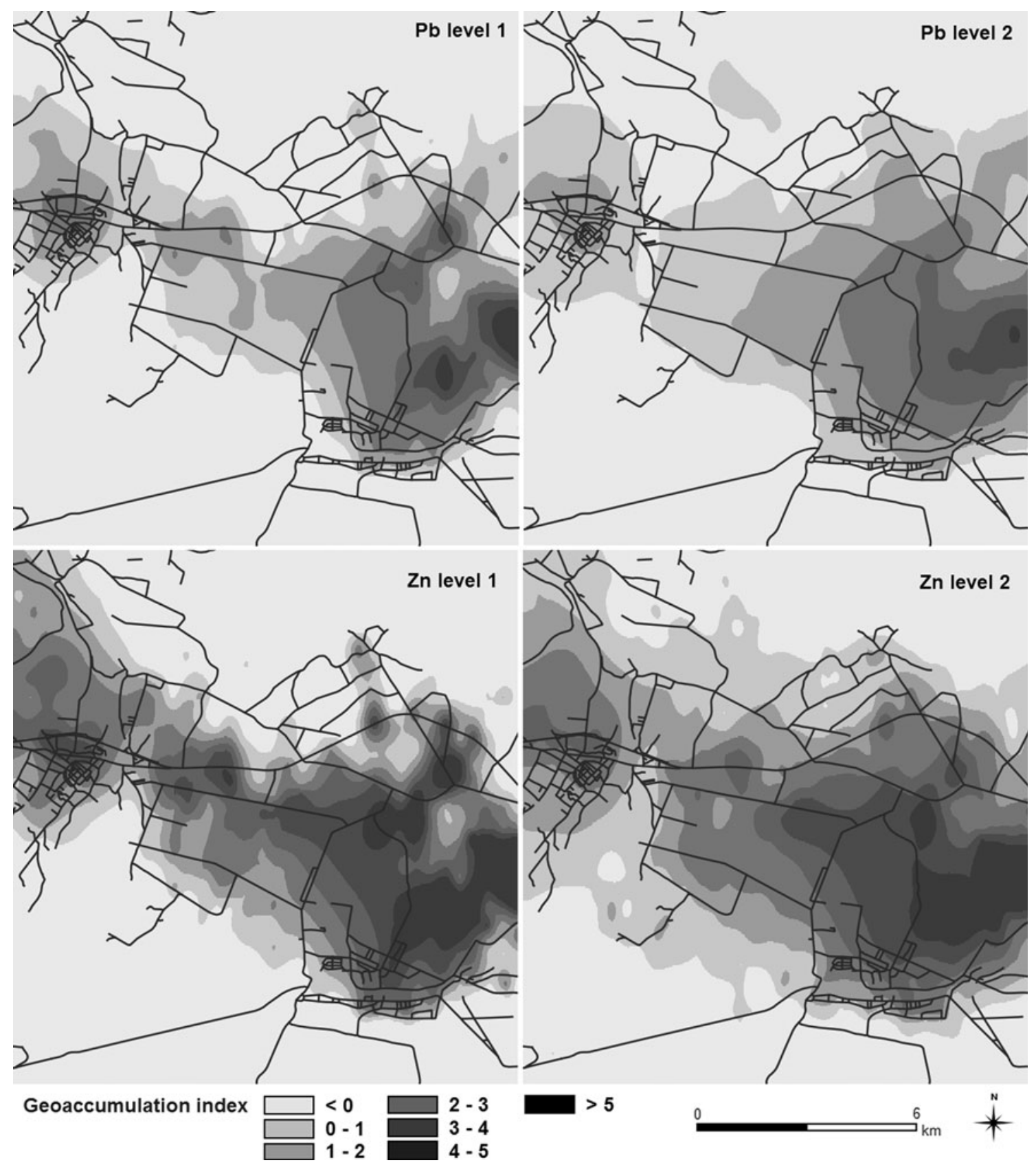

Fig. 8 Spatial distributions of geoaccumulation index calculated for concentration of $\mathrm{Pb}$ and $\mathrm{Zn}$ on levels 1 and 2

Geoaccumulation index and enrichment factor

The highest values of IG were observed in the vicinity of the mines, areas used for mining purposes and also near Sławków town. At this part of the study, area values of IG were 3 or higher which reveals that the contamination intensity was ranging from strong to very strong. Analogous values and spatial distributions of IG were observed for levels 1 and 2 for concentration of $\mathrm{Pb}$ and $\mathrm{Zn}$ and also similar similarity was observed for concentrations of both metals on the same level. It confirmed that the soil pollution at these parts of study area is strongly connected with the extraction of ores, in which concentration of $\mathrm{Pb}$ and $\mathrm{Zn}$ ores is highly correlated.

At the remaining parts of the study area, covered mostly by forests in the northern and north-eastern part as well as by post-mining area in the south-western part, the values of IG were low, ranging from 0 to 1 . It means that these parts of the study area were contaminated in low or at most medium level (Fig. 8).

The enrichment factor revealed similar spatial distribution as the geoaccumulation index. The highest values of 


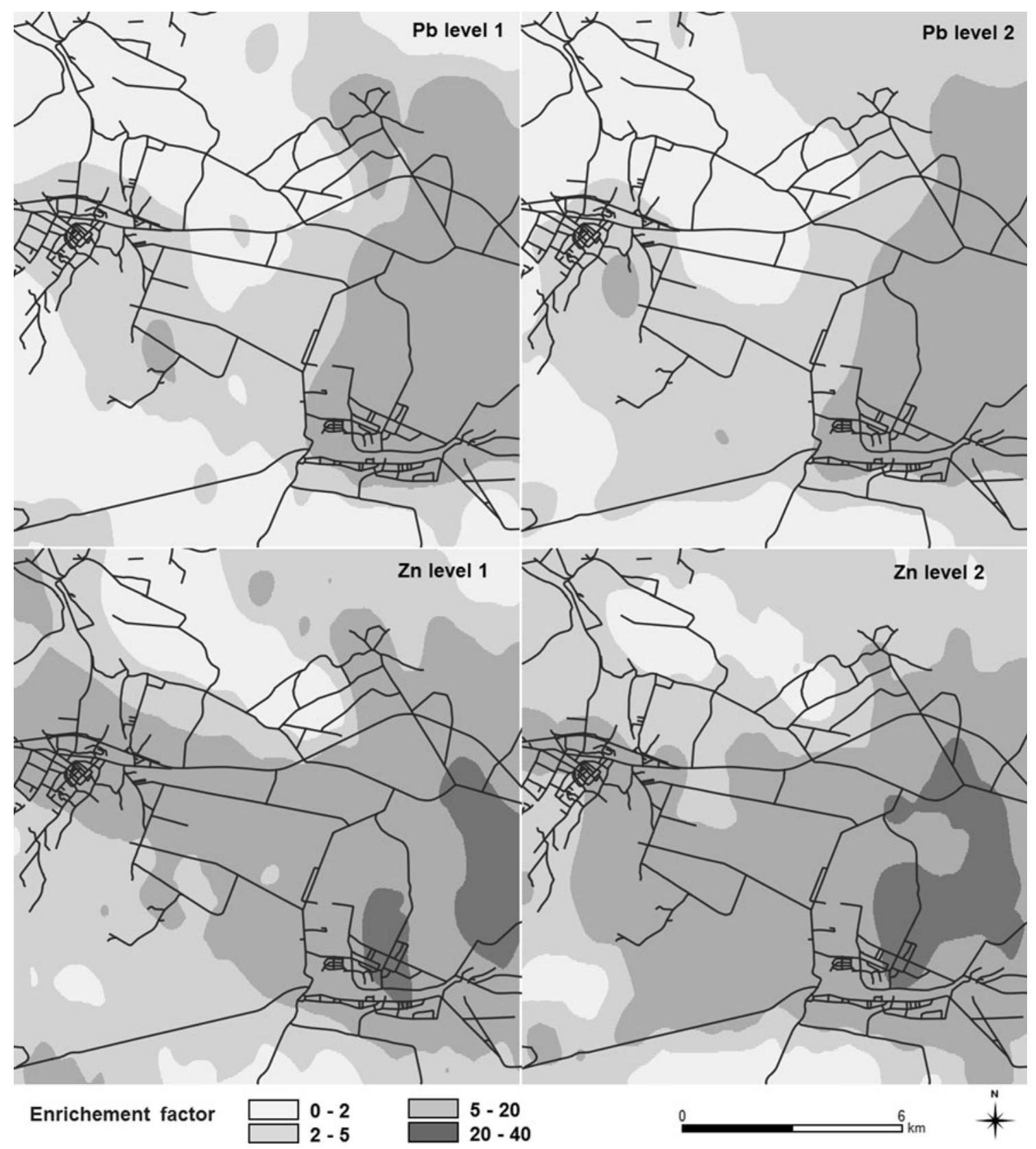

Fig. 9 Spatial distributions of enrichment factor calculated for concentration of $\mathrm{Pb}$ and $\mathrm{Zn}$ on levels 1 and 2

EF, exceeding 20 and reaching up to 40, were observed in nearby mining areas, which means very high to extremely high soil pollution. Such observations are consistent with the presence of ores rich in $\mathrm{Pb}$ and $\mathrm{Zn}$. In forest and postmining areas, where values of IG suggested low up to moderate contamination, values of EF ranged from 2 to 5 . Such results may suggest that these parts of the study area are not contaminated, but are characterized by rather significant natural enrichment with ores rich in $\mathrm{Pb}$ and $\mathrm{Zn}$ (Fig. 9).

\section{Conclusion}

In the entire study area, concentration of $\mathrm{Pb}$ and $\mathrm{Zn}$ in soil was several times higher at the depth of 40 to $60 \mathrm{~cm}$ beneath the soil surface than at the depth of up to $20 \mathrm{~cm}$. It resulted from shallow location of $\mathrm{Pb}$ and $\mathrm{Zn}$ ores. The highest concentrations of $\mathrm{Pb}$ and $\mathrm{Zn}$, on both levels in soil profile, were observed in mining areas, arable areas and in the vicinity of roads. For these areas, heightened concentrations were the result of anthropogenic pollution due to a 
short distance from mines to predominant wind directions where an enrichment factor and geoaccumulation index reached values of above 20 and 5, respectively.

The lowest concentrations of $\mathrm{Pb}$ and $\mathrm{Zn}$ were observed in forest and areas that were used for ore exploration in the past centuries. It was caused by presently low anthropogenic pressure and presence of sandy soils that are less capable of accumulating heavy metals. Moreover, values of geoaccumulation index less than 0 and moderate values of enrichment factor (0-5) suggest that observed $\mathrm{Pb}$ and $\mathrm{Zn}$ concentration in soil was rather caused by natural enrichment than by anthropogenic pollution.

The ranges of correlation for $\mathrm{Pb}$ and $\mathrm{Zn}$ concentration in the topmost soil layer were generally shorter than ranges of correlation in the soil layer at depths ranging from 40 to $60 \mathrm{~cm}$. In the case of $\mathrm{Zn}$, the highest differences were observed in forests (up to $24 \%$ ), in industrial areas located on sands and in arable areas located on loess (up to $27 \%$ in both cases). In contrast, in arable areas located on loams, $\mathrm{Zn}$ concentration in the deeper soil layer was characterized by significantly shorter correlation range. Correlation ranges of $\mathrm{Pb}$ concentration in the upper soil layer were shorter than those for deeper soil. Only in the case of post-mining area, correlation ranges were comparable. Clearer spatial dependence was observed for a deeper soil layer in comparison with a topmost layer, especially near mines where the anthropogenic factors were predominant over natural lithogenic ones.

Such observation was consistent with the results concerning enrichment factor and geoaccumulation index, because in the areas characterized by weak spatial dependence, high values of geoaccumulation index were observed.

Acknowledgments Authors want to thank to Polish Geological Institute for granting the access to the soil samples.

Open Access This article is distributed under the terms of the Creative Commons Attribution License which permits any use, distribution, and reproduction in any medium, provided the original author(s) and the source are credited.

\section{References}

Albasel N, Cottenie A (1985) Heavy metal contamination near major highways, industrial and urban areas in Belgian grassland. Water Air Soil Pollut 24(1):103-109

Bierkens MFP (1997) Using stratification and residual kriging to map soil pollution in urban areas. In: Bafi EY, Schofield NA (eds) Geostatistics Wollongong. Kluwer Academic Publishers, Dordrecht, pp 996-1007

Bossard M, Feranec J, Otahel J (2000) Corine land cover technical guide - Addendum 2000. Technical Report No 40, EEA, Copenhagen
Cabala J (2009) Metale ciężkie w środowisku glebowym olkuskiego rejonu eksploatacji rud $\mathrm{Zn}-\mathrm{Pb}$. Wydawnictwo Uniwersytetu Śląskiego, Katowice

Cabala J, Teper E, Teper L (2004) Mine-waste impact on soils in the Olkusz Zn-Pb ore district (Poland). In: Balkema (ed) Mine Planning and Equipment Selection, pp 755-760

Cambardella CA, Moorman TB, Novak JM, Parkin TB, Karlen DL, Turco RF, Konopka RF (1994) Field-scale variability of soil properties in central Iwoa soils. Soil Sci Soc Am J 58:1501-1511

Ettler V, Vanek A, Mihaljevic M, Bezdicka P (2005) Contrasting lead speciation in forest and tilled soils heavily polluted by lead metallurgy. Chemosphere 58:1449-1459

Gallego JLR, Ordonez A, Loredo J (2002) Investigation of trace element sources from an industrialized area (Aviles, northern Spain) using multivariate statistical methods. Environ Int 27:589-596

Goovaerts P (1997) Geostatistics for Natural Resources Evaluation. Oxford University Press, New York

Hani A, Pazira E (2011) Heavy metals assessment and identification of their sources in agricultural soils of Southern Tehran. Iran. Environ Monit and Assess 176(1-4):677-691

Hulett LD, Weinberger AJ, Northcutt KJ, Ferguson M (1980) Chemical species in fly ash from coal-burning power plant. Science 210:1356-1358

Isaaks EH, Srivastava RM (1989) An introduction to applied geostatistics. Oxford University Press, New York

Lis J, Pasieczna A (1999) Atlas geochemiczny Górnego Śląska. Polski Instytut Geologiczny, Warszawa

Loska K, Cebula J, Pelczar J, Wiechuła D, Kwapuliński J (1997) Use of enrichment, and contamination factors together with geoaccumulation indexes to evaluate the content of $\mathrm{Cd}, \mathrm{Cu}$, and $\mathrm{Ni}$ in the Rybnik Water Reservoir in Poland. Water Air Soil Pollut 93:347-365

Maas S, Scheifler R, Benslama M, Crini N, Lucot E, Brahmia Z, Benyacoub S, Giraudoux P (2010) Spatial distribution of heavy metal concentrations in urban, suburban and agricultural soils in a Mediterranean city of Algeria. Environ Pollut 158:2294-2301

Magiera T, Zawadzki J (2007) Using of high-resolution topsoil magnetic screening for assessment of dust deposition: comparison of forest and arable soil datasets. Environ Monit Assess 125:19-28

Magiera T, Strzyszcz Z, Kapička A, Petrovsky E (2006) Discrimination of lithogenic and anthropogenic influences on topsoil magnetic susceptibility in Central Europe. Geoderma 130:299311

Morton-Bermea O, Hernández-Álvarez E, González-Hernández G, Romero F, Lozano R, Beramendi-Orosco LE (2009) Assessment of heavy metal pollution in urban topsoils from the metropolitan area of Mexico City. J Geochem Explor 101:218-224

Qishlaqi A, Moore F, Forghani G (1997) Characterization of metal pollution in soils under two landuse patterns in the Angouran region, NW Iran; a study based on multivariate data analysis. J Hazard Mater 172:374-384

Reimann C, De Caritat P (2000) Intrinsic flaws of element enrichment factors (EFs) in environmental geochemistry. Environ Sci Technol 34:5084-5091

Rubio B, Nombela MA, Vilas F (2000) Geochemistry od major and trace elements in sediments of the Ria de Vigo (NW Spain) an assessment of metal pollution. Mar Pollut Bull 40(11):968-980

Saby N, Arrouays D, Jolivet C, Boulonne L, Pochot A (2006) Geostatistical assessment of $\mathrm{Pb}$ in soil around Paris. France. Sci Total Environ 67(1):212-221

Strzyszcz Z, Magiera T (1998) Heavy metal contamination and magnetic susceptibility in soils of southern Poland. Phys Chem Earth 23(9-10):1127-1131 
Sutherland RA (2000) Bed sediment-associated trace metals in an urban stream, Oahu. Hawaii. Environ Geol 39(6):611-627

Wei BG, Yang LS (2009) A review of heavy metal contaminations in urban soils, urban road dusts and agricultural soils from China. Microchem J 94:99-107
Zawadzki J, Fabijańczyk P (2008) The geostatistical reassessment of soil contamination with $\mathrm{Pb}$ in the Warsaw agglomeration. Int $\mathrm{J}$ Environ Pollut 35(1):1-13 